\title{
Catamenial pneumothorax - a review of the literature
}

\author{
Tomasz Marjański, Katarzyna Sowa, Aleksandra Czapla, Witold Rzyman \\ Department of Thoracic Surgery, Medical University of Gdansk, Poland \\ Kardiochirurgia i Torakochirurgia Polska 2016; 13 (2): 117-121
}

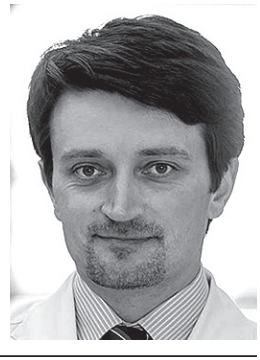

\begin{abstract}
Catamenial pneumothorax should be defined as recurrent accumulation of air in the pleural cavity in reproductive-age women without concomitant respiratory diseases. The sine qua non criterion is the occurrence of the pneumothorax in the period of 72 hours before or after the menses. Additional criteria include characteristic pleural lesions, right-sided occurrence, and coexistence of endometriosis. There are no radiological or pathological conditions allowing an exact confirmation of catamenial pneumothorax. In the case of catamenial pneumothorax, treatment failure most commonly consists in disease recurrence. It may occur even as late as several years after the initial treatment. The recurrence rate in patients undergoing surgery ranges from $8 \%$ to $40 \%$. Finding and resecting the visible pleural lesions is of key importance during surgical treatment. Reconstruction of the diaphragm must be performed in every patient in whom diaphragmatic perforations are found. Hormonal therapy seems to be effective in sustaining the effects of surgical treatment.

Key words: pneumothorax, catamenial pneumothorax, videothoracoscopy, endometriosis.
\end{abstract}

\section{Introduction}

Catamenial pneumothorax (i.e., pneumothorax occurring during the perimenstrual period) is a condition that has been recognized for several decades. Differences in its definition stem from the various definitions of the "perimenstrual period", which encompasses the period of 72 hours before and after menstrual bleeding. Marshall et al. have proposed to extend this period to 96 hours [1-9].

From $3 \%$ to $6 \%$ of spontaneous pneumothorax cases meet the definition of catamenial pneumothorax, constituting an indication for surgical treatment in $1 / 3$ of the affected women. The mean age of onset is 32-35 years [13, 8-12]. The condition may develop as late as at 39 years of age $[6,13]$. Catamenial pneumothorax is most often (85-95\%) unilateral, occurring on the right side of the chest, but it may also occur on the left side or bilaterally [9-15].

\section{Streszczenie}

Odma katamenialna powinna być definiowana jako nawracające pojawianie się powietrza w jamie opłucnej, stwierdzane u kobiet w wieku reprodukcyjnym, u których nie występują inne choroby płuc. Kryterium sine qua non rozpoznania odmy katamenialnej jest pojawienie się jej w ciągu 72 godzin przed rozpoczęciem i po rozpoczęciu krwawienia miesięcznego. Dodatkowymi kryteriami są: charakterystyczne zmiany opłucnowe, prawostronny charakter odmy oraz wspótistnienie endometriozy. Nie istnieją kryteria radiologiczne i anatomopatologiczne pozwalające na jednoznaczne rozpoznanie tej choroby. Najczęstszym niepowodzeniem leczenia odmy katamenialnej jest jej nawrót. Do nawrotu może dojść w ciągu kilku lat po pierwszym incydencie odmy, a ogólny wskaźnik nawrotów u pacjentek operowanych wynosi od $8 \%$ do $40 \%$. W trakcie zabiegów chirurgicznych konieczna jest dokładna obserwacja i usunięcie zmian z opłucnej ściennej i płucnej. Każdorazowo w przypadku stwierdzenia otworów w przeponie konieczna jest jej rekonstrukcja. Zaleca się również terapię hormonalną, która wydaje się pomocna w utrzymaniu efektów uzyskanych chirurgicznie. Słowa kluczowe: odma opłucnowa, odma katamenialna, wideotorakoskopia, endometrioza.

The etiopathogenesis of catamenial pneumothorax is explained by the following theories: physiological, migrational, microembolic-metastatic, and the diaphragmatic theory of air "passage" (Table I).

There are no pathognomonic anatomopathological changes for this nosological entity, and the diagnosis is established based on clinical features. Catamenial pneumothorax is associated with the following findings: single or multiple fenestrations in the tendinous part of the diaphragm; red/brown spots or nodules located on the diaphragmatic or visceral pleura. Histopathological analysis of these nodules (spots) reveals glandular cells, endometrial stroma, and macrophages filled with hemosiderin, whereas immunohistochemical testing may demonstrate the presence of estrogen and progesterone receptors $[2-5,12,13$, 15-18]. These findings are observed if pneumothorax is ac-

Address for correspondence: Dr. Tomasz Marjański, Department of Thoracic Surgery, Medical University of Gdansk, 17 Smoluchowskiego St, 80-952 Gdansk, Poland, phone: +48 583493 142, e-mail: marjanski@gumed.edu.pl 
Tab. I. Theories for the development of thoracic foci of endometriosis

\begin{tabular}{ll}
\hline Physiological & $\begin{array}{l}\text { High concentration of prostaglandin F2 during menses may cause blood vessels and bronchioles } \\
\text { to contract, which leads to alveolar rupture and development of pneumothorax. }\end{array}$ \\
\hline Migrational & $\begin{array}{l}\text { Endometrial cells may migrate from the uterus, through the fallopian tubes, into the lesser pelvis } \\
\text { and further, into the area of the diaphragm. The cyclical proliferation and necrosis of endome- } \\
\text { trial cells may injure the diaphragm, enabling the cells to migrate further into the chest and the } \\
\text { visceral pleura, which may lead to pulmonary alveolar injury and pneumothorax. }\end{array}$ \\
\hline Microembolic-metastatic & $\begin{array}{l}\text { Metastatic spread or pulmonary microembolization from endometrial cells through blood or } \\
\text { lymph vessels. Necrosis of subpleural interstitial endometriotic foci leads to pneumothorax; foci } \\
\text { located more centrally cause hemoptysis. }\end{array}$ \\
\hline Diaphragmatic theory of air "passage" & $\begin{array}{l}\text { Air passes through the uterus and fallopian tubes into the peritoneal cavity and, through diaph- } \\
\text { ragmatic fenestrations, into the pleural cavity. }\end{array}$ \\
\hline
\end{tabular}

companied by endometriosis, especially within the pelvis, as occurs in $30-51 \%$ of cases.

Treatment for catamenial pneumothorax involves hormonal therapy and surgical treatment (wedge lung resection, pleurectomy, chemical or mechanical pleurodesis, and diaphragm reconstruction - direct or using synthetic meshes).

\section{History}

In 1938, Schwarz presented a hypothesis concerning the concomitance of hemoptysis and menstruation in women [18]. In 1953, Barnes described concurrent endometriosis and pleural hematomas [19], but the coexistence of these conditions was not unequivocally confirmed.

Recurrent pneumothorax concomitant with menses was described by Maurer et al. in 1958 [20]. The first definition of catamenial pneumothorax comes from 1972 and is credited to Lillington et al. [21].

\section{Terms and definitions}

Catamenial pneumothorax should be defined as recurrent appearance of air in the pleural cavity in reproductiveage women who do not suffer from other lung diseases. The sine qua non criterion for the diagnosis of catamenial pneumothorax is its appearance within 72 hours before or after the start of monthly bleeding. The additional criteria include: characteristic pleural lesions, right-sided location of the pneumothorax, and concomitant endometriosis.

The symptoms of catamenial pneumothorax are typical of spontaneous pneumothorax, but the condition may also be asymptomatic.

The temporal correlation between menstruation and catamenial pneumothorax has not been unequivocally determined [17]. Medical literature attempts to specify the temporal relationship between catamenial pneumothorax and menstruation using expressions such as pneumothorax correlated with [22], associated with [16], synchronized with [23], during [6, 14], preceding [8], or close to [24] the menstrual period. The broadest definitions of catamenial pneumothorax describe it as pneumothorax occurring from 7 days before the start of monthly bleeding to 7 days after its completion. A clear name should be selected for the Polish language in order to unambiguously indicate the rela- tionship between pneumothorax and menstrual bleeding, e.g. odma miesięczna ("monthly pneumothorax").

\section{Concomitant endometriosis}

Catamenial pneumothorax may be associated with the occurrence of thoracic endometriosis [2-5, 11, 14, 24-26]. Concomitance of catamenial pneumothorax and endometriosis was described in a woman in the $8^{\text {th }}$ week of pregnancy [27].

Thoracic endometriosis is defined as the presence of ectopic endometrium within the chest, the symptoms of which appear during ovulation [11].

Symptoms of pelvic endometriosis, secondary or primary infertility, and previous gynecological procedures [1, 3-5] may suggest the diagnosis of catamenial pneumothorax in the course of endometriosis.

During laparoscopic treatment of pelvic endometriosis, endometrial implants can be found in the diaphragm. Endometrial implants occurred individually (30\%) or in groups (70\%) in patients undergoing surgery. The implants developed on the right side in $87 \%$ of the patients, and on the left only in $11 \%$. Left-sided diaphragmatic foci of endometriosis are a rare phenomenon - they make up only approximately $2 \%$ of the intraoperative findings [28].

A review of the treatment results of 110 patients with thoracic endometriosis revealed that pneumothorax occurred in $72 \%$ of the women, hemoptysis in $14 \%$, pleural hematomas in $12 \%$, and lung nodules in $2 \%$ [11]. Pelvic endometriosis may precede the development of thoracic endometriosis by 5 years [12]. Despite the fact that the most common manifestation of thoracic endometriosis is pneumothorax [11, 12], in some cases of catamenial pneumothorax, endometrial character of the disease cannot be confirmed histologically [5, 9, 22]. Abnormal fenestrations in the tendinous part of the diaphragm can be observed during surgical procedures performed on patients suffering from catamenial pneumothorax concomitant with endometriosis. Furthermore, the patients' pleurae feature spots and nodules which are endometrial implants. The lesions are most often located on the diaphragmatic pleura.

Bagan et al. point to the increase in the serum titer of the Ca125 antigen as a helpful marker of catamenial pneumothorax associated with endometriosis [29]. In accordance 
with the presented data, the value of Ca125 that indicates high probability of endometriosis is $76 \mathrm{U} / \mathrm{ml}$. In a study published by Haga in 2013, an increase of the Ca125 antigen to $36.7 \pm 42.3 \mathrm{U} / \mathrm{ml}$ was considered significant [13]. However, the marker is not specific, which limits its routine use.

\section{Radiological diagnostics}

There are no unequivocal criteria for the diagnosis of this condition. Radiologically, catamenial pneumothorax may be suspected in cases of pneumoperitoneum concomitant with right-sided pneumothorax [30]. Additional criteria are extensive diaphragmatic defects, diaphragmatic hernia involving the liver [31], and small diaphragmatic defects described as "air-filled bubbles" corresponding to perforations within the diaphragm [15]. Computed tomography can reveal endometrial nodules on the surface of the diaphragm [22]. Although magnetic resonance may facilitate the visualization of endometriotic foci [32], the routine performance of this examination in the case of pneumothorax does not currently appear justified.

\section{Treatment}

Video-assisted thoracoscopic surgery (VATS) is the access of choice in the treatment of pneumothorax. Thoracotomy is indicated almost exclusively in cases of recurrence after a previous procedure. The use of video-assisted mini-thoracotomy has been suggested if the procedure involves extensive lesions within the diaphragm [1, 4, 5, 9, 14, $22,23]$. Most authors are in agreement in their recommendations to perform bullectomy, pleurectomy, or pleurodesis. The main subject of contention is the extent of the intervention within the diaphragm, especially if no pathology is found in this area. It should be stressed that any woman in reproductive age who is operated on due to pneumothorax should undergo a detailed pulmonary examination. As in the case of laparoscopy performed within the lesser pelvis, all suspected endometriotic foci must be removed from the pleural cavity and sent for histopathological testing. The extent of the procedure resembles that of metastasectomy performed due to oncological indications.

In the case of catamenial pneumothorax associated with thoracic endometriosis, Joseph et al. suggest that surgery is more effective than hormonal pharmacotherapy because of the lower rates of long-term recurrence: during a follow-up of 1 year, recurrence occurred in $30 \%$ of the patients treated with surgery and $60 \%$ of the patients receiving pharmacological treatment [12]. The largest review of treatment results was published by Korom et al. Out of the 229 catamenial pneumothorax patients whose cases were published in the literature, the authors selected 194 individuals (patients with adequate information), of whom $79 \%$ were treated with surgery. In $82 \%$ of the patients, pleurodesis was performed with or without diaphragm repair, or with pulmonary wedge resection. Pulmonary wedge resection alone constituted $20 \%$ of the performed procedures; surgical repair of diaphragmatic defects was necessary in $39 \%$ of patients [16]. According to Korom et al., the mean time until recurrence is 24 months after diaphragm removal with or without pleurodesis and 61 months after pleurodesis [16]. These results appear not to be associated with the extent of the procedure, but rather with the significant influence of the presence of diaphragmatic defects on the increased rate of recurrence. In 2005, Marshall et al. suggested that, in the case of catamenial pneumothorax accompanied by radiologically visualized lesions, extensive surgery is recommended, consisting in diaphragmatic resection, bullectomy, pleurodesis, or pleurectomy [8]. Contrary to traditional surgical recommendations, Bagan et al. proposed to perform surgical procedures during menstruation in order to avoid overlooking small and hidden lesions in the pleurae and the diaphragm. The aim of performing the procedure during this period is to provide precise visualization of the endometrial lesions and to cover the diaphragm with a polyglactin mesh instead of performing a resection, which is meant to provide protection from recurrence [33]. The use of a mesh (polyglactin or polypropylene) and the performance of pleurodesis are also recommended by Leong et al. [7]. Alifano et al. recommend resecting all visible lesions (as an optimal treatment and a method of preventing their spread). These procedures may involve partial resection of the diaphragm, resection of pulmonary foci/emphysematous bullae, and resection of the parietal pleura in order to remove the lesions from this area [1]. Resections of implants within the visceral pleura have also been performed [4]. Alifano et al. also observed that, in a group of 114 patients operated on due to spontaneous pneumothorax between 2000 and 2006, the recurrence rate was 32\% for catamenial pneumothorax and $27 \%$ for non-catamenial pneumothorax. The duration of follow-up was 33 months [3]. The treatment results of 37 patients with catamenial pneumothorax indicate that diaphragm resection with pleurodesis, supplemented with hormonal treatment, offers satisfactory results [34]. The authors also recommend diaphragm resection instead of suturing or plication because of its higher effectiveness and the option to secure material for histological analysis [5]. Ciriaco et al. presented the results of treatment consisting in pleurodesis with lung apex excision, partial pleurectomy, and, when lesions were found, diaphragm plication [22]. The publication reported pneumothorax recurrence in $40 \%$ of the patients during 52 months of follow-up. The authors underscored the favorable effect of hormonal therapy [22]. In 2012, Attaran et al. presented the results of VATS pleurectomy supplemented with diaphragm reconstruction using polytetrafluoroethylene (PTFE) mesh to cover the lesions visible on the diaphragm [10, 35]. In a small group of 12 patients in whom extensive surgery (abrasion, pleurectomy, PTFE mesh) and hormonal treatment were employed, the researchers observed recurrence in $8 \%$ of the patients. The recurrence occurred before the start of hormonal therapy. The follow-up was 46 months [10]. Haga et al. reported recurrence in 39\% of 92 patients diagnosed with catamenial pneumothorax. The study encompassed 690 women who underwent surgical treatment due to spontaneous pneumothorax. 
Most authors underscore the significance of precise evaluation of diaphragmatic, pericardial, pleural, and pulmonary surfaces as well as the necessity of treating lesions in these locations. Obtaining material for histological analysis facilitates confirming the diagnosis of catamenial pneumothorax in the course of endometriosis [4].

In the case of catamenial pneumothorax, treatment failure most commonly consists in the recurrence of the condition [4, 33]. Catamenial pneumothorax may recur within several years after the first episode; the general rate of recurrence in patients undergoing surgery ranges from $8 \%$ to $40 \%$.

There are no clear-cut guidelines for the treatment of catamenial pneumothorax and the prevention of its recurrence. The common element of the treatment methods is pneumothorax decompression if the patient's life is in danger. The effectiveness of both surgical treatment and hormonal therapy varies in terms of recurrence prevention. Each treatment method has its limitations and fails to guarantee sufficient efficacy [34].

Pharmacological treatment for endometriosis should be conducted by a gynecologist. The primary aim of treatment is to induce hypoestrogenism, resulting in the lack of menses. This is meant to atrophy the endometrium, including the ectopic endometrium. When deciding whether to start hormonal therapy, the woman's plans concerning pregnancy are considered. The therapies most often employ oral contraceptive pills (estrogen-progestogen) inducing menses every 28 days or used continuously (without inducing menses). The employed agents also include progestogens, which may be administered orally, intramuscularly, or as intrauterine systems. Other medications are also used. Pharmacotherapy is recommended in the case of catamenial pneumothorax associated with endometriosis. The diagnosis should be confirmed on the basis of histological examination, and hormonal therapy starts after surgical treatment $[4,8,10,22]$. Hormonal therapy alone is considered effective in preventing recurrence in patients with significant perioperative risk. Haga et al. discuss the effectiveness of hormonal therapy even though it was only used in some of the women [13].

The fact that a patient has undergone surgical treatment for pneumothorax should not influence the obstetric decisions concerning the methods of child delivery. The literature data on this subject are insufficient.

Due to the multi-specialty character of the disease's treatment, its chronic course, requiring numerous surgical interventions in various body cavities or long-term pharmacotherapy, and the relatively unpredictable treatment results, the treatment provided to patients with catamenial pneumothorax should be conducted by multi-specialist teams. Furthermore, patients with this condition should be instructed to seek gynecological consultation due to the possibility of concomitant uterine endometriosis.

Discrepancies in the rates of recurrence or the mean age of disease development stem from the small size of the study groups and the differences in the length of follow-up.

\section{Conclusions}

Catamenial pneumothorax should be suspected in young women with pneumothorax during the perimenstrual period. Treatment failure in the case of catamenial pneumothorax most commonly consists in the recurrence of the condition. During surgery, it is necessary to carefully observe and remove the lesions from the parietal and visceral pleura. Diaphragm reconstruction is required each time when fenestrations are found in this structure. Hormonal therapy is also recommended, as it appears to facilitate maintaining the effects achieved with surgery.

\section{Disclosure}

Authors report no conflict of interest.

\section{References}

1. Alifano M, Roth T, Broët SC, Schussler O, Magdeleinat P, Regnard JF. Catamenial pneumothorax: a prospective study. Chest 2003; 124: 1004-1008.

2. Alifano M, Trisolini R, Cancellieri A, Regnard JF. Thoracic endometriosis: current knowledge. Ann Thorac Surg 2006; 81: 761-769.

3. Alifano M, Jablonski C, Kadiri H, Falcoz P, Gompel A, Camilleri-Broet S, Regnard JF. Catamenial and noncatamenial, endometriosis-related or nonendometriosis-related pneumothorax referred for surgery. Am J Respir Crit Care Med 2007; 176: 1048-1053.

4. Alifano M. Catamenial pneumothorax. Curr Opin Pulm Med 2010; 16: 381-386.

5. Alifano M, Legras A, Rousset-Jablonski C, Bobbio A, Magdeleinat P, Damotte $D$, Roche N, Regnard JF. Pneumothorax recurrence after surgery in women: clinicopathologic characteristic and management. Ann Thorac Surg 2011; 92: 322-326.

6. Cowl CT, Dunn WF, Deschamps C. Visualisations of diaphragmatic fenestration associated with catamenial pneumothorax. Ann Thorac Surg 1999; 68: 1413-1414.

7. Leong AC, Coonar AS, Lang-Lazdunski L. Catamenial pneumothorax: surgical repair of the diaphragm and hormone treatment. Ann R Coll Surg Engl 2006; 88: 547-549.

8. Marshall MB, Ahmed Z, Kucharczuk JC, Kaiser LR, Shrager JB. Catamenial pneumothorax: optimal hormonal and surgical management. Eur J Cardiothorac Surg 2005; 27: 662-666.

9. Rousset-Jablonski C, Alifano M, Plu-Bureau G, Camilleri-Broet S, Rousset P, Regnard JF, Gompel A. Catamenial pneumothorax endometriosis-related pneumothorax: clinical features and risk factors. Hum Repord 2011; 26: 2322-2329.

10. Attaran S, Bille A, Karenovics W, Lang-Lazdunski L. Videothoracoscopic repair of diaphragm and pleurectomy/abrasion in patients with catamenial pneumothorax: a 9-year experience. Chest 2013; 143: 1066-1069.

11. Channabasavaiah AD, Joseph JV. Thoracic endometriosis: revisiting the association between clinical presentation and thoracic pathology based on thoracoscopic findings in 110 patients. Medicine (Baltimore) 2010; 89: 183-188.

12. Joseph J, Sahn SA. Thoracic endometriosis syndrome: new observation from an analysis of 110 cases. Am J Med 1996; 100: 164-170.

13. Haga T, Kurihara $M$, Kataoka $H$, Ebana $H$. Clinical-pathological findings of catamenial pneumothorax: comparison between recurrent cases and nonrecurrent cases. Ann Thorac Cardiovasc Surg 2014; 20: 202-206.

14. Majak P, Langebrekke A, Hagen OM, Qviqstad E. Catamenial pneumothorax, clinical manifestations - a multidisciplinary challenge. Pneumonol Alergol Pol 2011; 79: 347-350.

15. Roth T, Alifano M, Schussler O, Magdaleinat P, Regnard JF. Catamenial pneumothorax: chest X-ray sign and thoracoscopic treatment. Ann Thorac Surg 2002; 74: 563-565.

16. Korom S, Canyurt H, Missbach A, Schneiter D, Kurrer MO, Haller U, Keller PJ, Furrer M, Weder W. Catamenial pneumothorax revisited: clinical approach and systematic review of literature. J Thorac Cardiovasc Surg 2004; 128: 502-508.

17. Visouli AN, Darwiche K, Mpakas A, Zarogoulidis P, Papagiannis A, Tsakiridis K, Machairiotis N, Stylianaki A, Katsikogiannis N, Courcoutsakis N, Zarogoulidis K. Catamenial pneumothorax: a rare entity? Report of 5 cases and review of the literature. J Thorac Dis 2012; 4 Suppl 1: 17-31.

18. Schwarz O. Endometriosis of the lung. Am j Obstet Gynecol 1938; 36: 887-889. 
19. Barnes J. Endometriosis of the pleura and ovaries. J Obstet Gynecol Br Emp 1953; 60: 823-824.

20. Maurer ER, Schall JA, Mendez FL. Chronic recurring spontaneus pneumothorax due to endometriosis of the diaphragm. JAMA 1958; 168: 2013-2014.

21. Lillington GA, Mitchell SP, Wood GA. Catamenial pneumothorax. JAMA 1972; 219: 1328-1332.

22. Ciriaco P, Negri G, Libretti L, Carretta A, Melloni G, Casiraghi M, Bandiera A, Zannini P. Surgical treatment of catamenial pneumothorax: a single centre experience. Interact Cardiovasc Thorac Surg 2009; 8: 349-352.

23. Mikroulis DA, Didilis VN, Konstantinou F, Vretzakis GH, Bougioukas GI. Catamenial pneumothorax. Thorac Cardiovasc Surg 2008; 56: 374-375.

24. Peikert T, Gillespie DJ, Cassivi SD. Catamenial pneumothorax. Mayo Clin Proc 2005; 80: 677-680.

25. Alifano M, Venissac N, Mouroux J. Recurrent pneumothorax associated with thoracic endometriosis. Surg Endosc 2000; 14: 680.

26. Van Schil PE, Vercauteren SR, Vermeire PA, Nackaerts YH, Van Marck EA. Catamenial pneumothorax caused by thoracic endometriosis. Ann Thorac Surg 1996; 62: 585-586.

27. Yoshioka H, Fukui T, Mori S, Usami N, Nagasaka T, Yokoi K. Catamenial pneumothorax in a pregnant patient. Jpn J Thorac Cardiovasc Surg 2005; 53: 280-282.

28. Ceccaroni M, Roviglione G, Giampaolino P, Clarizia R, Bruni F, Ruffo G, Patrelli TS, De Placido G, Minelli L. Laparoscopic surgical treatment of diaphrag- matic endometriosis: a 7-year single-institution retrospective review. Surg Endosc 2013; 27: 625-632.

29. Bagan P, Berna P, Assouad J, Hupertan V, Le Pimpec Barthes F, Riquet M. Value of cancer antigen 125 for diagnosis of pleural endometriosis in females with recurrent pneumothorax. Eur Respir J 2008; 31: 140-142.

30. Downey DB, Towers MJ, Poon PY, Thomas P. Pneumoperitoneum with catamenial pneumothorax. AJR Am J Roentgenol 1990; 155: 29-30.

31. Bobbio A, Carbognani P, Ampollini L, Rusca M. Diaphragmatic laceration, partial liver herniation and catamenial pneumothorax. Asian Cardiovasc Thorac Ann 2007; 15: 249-251.

32. Picozzi G, Beccani D, Innocenti F, Grazzini M, Mascalchi M. MRI features of pleural endometriosis after catamenial haemothorax. Thorax 2007; 62: 744

33. Bagan P, Le Pimpec Barthes F, Assouad J, Souilamas R, Riquet M. Catamenial pneumothorax: retrospective study of surgical treatment. Ann Thorac Surg 2003; 75: 378-381

34. Cieslik L, Haider SS, Fisal L, Rahmaan J, Sachithanandan A. Minimaly invasive thoracoscopic mesh repair of diaphragmatic fenestrations for catamenial pneumothorax due to likely endometriosis: a case report. Med J Malaysia 2013; 68: 366-367.

35. Attaran M, Falcone T, Goldberg J. Endometriosis: still tough to diagnose and treat. Cleve Clin J Med 2002; 69: 647-653. 